\title{
SIMUNOVICH AND THE DEFENCE OF TRUTH
}

\author{
Emily Buist-Catherwood*
}

APN New Zealand Limited v Simunovich Fisheries Limited was a significant Supreme Court judgment regarding the biggest defamation claim in New Zealand's legal history. The Court ruled that third party statements were inadmissible as evidence for a defence of truth, unless such statements could be independently proven to be true. This paper argues that objectively reliable third party statements, such as statements made by the judiciary, should be admissible as evidence for a defence of truth in certain cases. Where a defamatory meaning of reasonable grounds to suspect guilt is pleaded, rather than an allegation of actual guilt, reliable statements made by a third party can be highly relevant in proving the existence of reasonable grounds for suspicion. A high burden is already placed on defendants to negotiate technical pleading and evidential requirements in proving the defence of truth. Simunovich erects an unnecessary further obstacle that will prevent the submission of relevant and reliable evidence. This paper recommends that the Simunovich ruling on third party statements be amended to allow such particulars to be admitted in support of a defence of truth to an alleged defamatory meaning of reasonable grounds of suspicion.

\section{INTRODUCTION}

The Supreme Court judgment in APN New Zealand Ltd $v$ Simunovich Fisheries Ltd (Simunovich) was a significant defamation law ruling that determined the necessary pleading and evidential requirements to prove a defence of truth. In the biggest defamation claim in New Zealand's legal history, Simunovich Fisheries claimed it was defamed by media allegations of corruption in the fishing industry.

This paper will analyse and assess Simunovich with a focus on its treatment of the defence of truth for a defamation claim. The defence of honest opinion was also discussed in the case, but is outside the scope of this study. ${ }^{1}$ Simunovich rules on the requirements for the establishment of a

* Submitted as part of the LLB(Hons) degree at Victoria University of Wellington. I would like to thank my supervisor, Professor Campbell McLachlan QC, for his invaluable help and support.

1 APN New Zealand Limited v Simunovich Fisheries Ltd [2009] NZSC 93, [2010] 1 NZLR 315 at [36] [Simunovich $(\mathrm{SC})]$. 
successful defence of truth, and clarifies issues relating to the form of pleadings necessary for the defence in light of the statutory and common law requirements. The Court needed to consider the implications of the common law repetition and conduct rules, and synthesise these principles with the requirements in the Defamation Act 1992 and the Evidence Act 2006. Significantly, Simunovich states that third party statements are inadmissible as evidence for a defence of truth, if such statements cannot be independently proven to be true. Potential particulars and admissible evidence are thus further limited in the case, even if the evidence comes from an objectively reliable source. This essay argues that the Simunovich ruling is too restrictive where a defamatory meaning of reasonable grounds to suspect guilt is pleaded, rather than an allegation of actual guilt. Objectively reliable third party statements, such as those made by the judiciary, may be highly relevant factors in proving the existence of true grounds for suspicion, and should not be excluded as evidence for the defence of truth.

The future implications of the ruling in Simunovich for media publishers will also be discussed. Simunovich places a high burden on the media, requiring them to be able to prove the truth of a story that may be defamatory by verifying any third party sources they rely on. This constraint could be desirable as it gives added protection to a defamed plaintiff and will dissuade the media from publishing unreliable stories. However, it will now be harder for defendants to succeed with a defence of truth. It is debatable whether or not the Simunovich ruling is a justifiable restriction on the rights of publishers to freedom of expression. Given that the defence was already considered difficult to establish, Simunovich will lead the media to self-impose further restrictions on what they publish to avoid proceedings where they may fail to make out a defence of truth. The ruling in Simunovich on the establishment of a defence of truth is likely to have considerable repercussions on media reporting. These effects will be especially significant in New Zealand where there is only a limited defence of qualified privilege, unlike in the United Kingdom where a wider defence based on responsible journalism is available.

This essay recommends that the rule in Simunovich on third party statements be amended by inserting a specific provision into the Defamation Act 1992 allowing for an evidential exception. Third party particulars should be admissible in support of a defence of truth to a defamation claim alleging reasonable grounds for suspicion, where the statements come from an objectively reliable source.

\section{DEFAMATION AND THE DEFENCE OF TRUTH}

\section{A Summary of Existing Law (Prior to Simunovich)}

The tort of defamation provides a cause of action where a person's reputation has been damaged.

To succeed, the plaintiff must establish that a defamatory statement was made about the plaintiff 
and published by the defendant. ${ }^{2}$ The truth defence permits media to defend themselves in publishing true statements that are held to be defamatory. There is no right to publish falsehoods about a person, but a plaintiff should not succeed in claiming injury to a reputation that they ought not to possess. ${ }^{3}$ Truth can provide a complete defence to a defamation action if proven on the balance of probabilities. ${ }^{4}$ Rather than the plaintiff proving that the statements made were false, the defendant must satisfy the court that the imputations in the words complained of were true or not materially different from the truth. ${ }^{5}$ After thoroughly analysing the state of defamation law, the Committee on Defamation noted in its influential report that this onus is difficult to discharge when the information has been obtained from secondary sources, however reliable. ${ }^{6}$ Truth can apply regardless of the motive of the defendant or the subject matter of the statement. ${ }^{7}$ Existing common law and statutory principles further regulate the pleadings, particulars and evidence required to establish a successful defence of truth.

\section{Pleadings and particulars}

Pleadings and particulars identify what facts are in issue. The plaintiff must give particulars of the defamatory meanings that the statement is alleged to bear. ${ }^{8}$ The defendant can then plead the truth of the words. ${ }^{9}$ A defendant must give particulars detailing the allegedly defamatory meanings he or she seeks to justify and the facts and circumstances relied upon to establish the defence of truth. ${ }^{10}$ This requirement informs the plaintiff fairly of the information on which the defendant relies. Necessary particulars may differ depending on the defamatory meaning and level of innuendo alleged by the plaintiff.

(a) Tiers of meaning

2 Hulton v Jones [1910] AC 20 (HL); Morgan v Odhams Press Ltd [1971] 1 WLR 1239 (HL); Stephen Todd (ed) The Law of Torts in New Zealand (5th ed, Brookers, Wellington, 2009) at 734.

3 I Loveland (ed) Importing the First Amendment: Freedom of Speech and Expression in Britain, Europe and USA (Hart Publishing, Oxford, 1998) at 24; M'Pherson v Daniels (1829) 10 B \& C 263, 109 ER 448 (KB) at 272 .

4 Scott v Gudsell (1884) 3 NZLR 119 (SC).

5 Defamation Act 1992, s 8; Television New Zealand Ltd v Haines [2006] 2 NZLR 433 (CA) at [55].

6 Committee on Defamation Recommendations on the Law of Defamation (1977) at 35 [the McKay Report].

7 Ibid, at 31 .

8 Laws of New Zealand Equity (online ed) at [77]; The McKay Report, above n 6, at 35.

$9 \quad$ Swainson \& Bevan Ltd v Hadfield [1904] 23 NZLR 43 (SC).

10 Laws of New Zealand, above n 8, at [76]. 
Lewis $v$ Daily Telegraph considered the linguistic problems involved in ascertaining a defamatory meaning. ${ }^{11}$ The allegedly defamatory words in question may convey different categories of allegations to the ordinary reader. Chase v News Group Newspapers Ltd distinguished between three tiers of defamatory meaning that arise in pleadings. ${ }^{12} \mathrm{~A}$ "tier one" meaning alleges actual misconduct by the plaintiff, "tier two" asserts that there are grounds to believe the plaintiff is guilty of misconduct, and "tier three" imputes that there are grounds for investigating whether the plaintiff is guilty of misconduct. This classification is in widespread use in England, but is not yet common in New Zealand. Simunovich confirmed that the tiers are a relevant method of description, but added that they should not dictate the meaning of the words in issue. ${ }^{13}$ These tiers are a practical tool for determining the meaning of allegedly defamatory words, and can assist in defining the permissible scope of particulars. ${ }^{14}$

(b) Repetition and conduct rules

Two common law principles further govern what a defendant is entitled to plead in support of a defence. English courts have accepted and developed the repetition and conduct rules. ${ }^{15}$ These had not been directly challenged in New Zealand until Simunovich. The repetition rule states that if you report or publish a defamatory statement, you are liable for repeating it even if it is attributed to an apparently reputable source. ${ }^{16}$ Publicly repeating a statement can be effectively the same as making a direct statement. ${ }^{17}$ The allegation of the rumour itself must be true, not just that it has been said by someone else. ${ }^{18}$ The defence of privilege is an exception to this rule. ${ }^{19}$ Some argue that the repetition rule applies only to "tier one" imputations asserting guilt. ${ }^{20}$ However, the English Court of Appeal held that this view would let defendants couch defamatory statements in "tier two" or "three" terms, then justify those statements on the basis of repeating assertions of others, rather than

11 Lewis v Daily Telegraph Ltd [1964] AC 234 (HL) at 282.

12 Chase v News Group Newspapers Ltd [2002] EWCA Civ 1772, [2003] EMLR 11 (CA) at [45].

13 Simunovich (SC), above n 1, at [16].

14 Ibid.

15 Lewis v Daily Telegraph Ltd, above n 11; Stern v Piper [1997] QB 123 (CA); Shah v Standard Bank [1999] QB 241 (CA).

16 Truth NZ Ltd v Holloway [1961] NZLR 22 (PC).

17 Rubber Improvements Ltd v Daily Telegraph Ltd [1964] 2 All ER 151 (HL) at 173.

18 Lewis v Daily Telegraph Ltd, above n 11, at 283.

19 Patrick Milmo and W V H Rogers (eds) Gatley on Libel and Slander (11th ed, Thomson Reuters, London, 2008) at 314.

20 Jameel $v$ Times Newspapers Ltd [2004] EWCA Civ 983, [2004] EMLR 31 at [29]. 
having to prove their underlying truth. ${ }^{21}$ This paper argues that statements made by a reliable third party should be admissible for the purpose of proving the truth of a defamatory imputation of reasonable suspicion. This proposal would not necessarily mean that the allegedly defamatory statements were justified simply by attributing them to another source, but these earlier statements could be considered in looking at whether reasonable grounds for suspicion or investigation did exist. The risk of a defendant framing all allegations in tier two or three terms, to avoid having to prove the truth of actual misconduct, is somewhat mitigated by the common law conduct rule. The conduct rule states that truth can only succeed as a defence to a tier two alleged meaning where the reasonable grounds for suspicion are based on some conduct of the plaintiff. ${ }^{22}$ The defendant is required to give direct particulars of the relevant conduct of the plaintiff that has given rise to suspicion.

(c) Defamation Act 1992

The Defamation Act 1992 was the product of important developments surrounding defamation law in New Zealand. The statute enacted many recommendations originating from the 1977 Report of the Committee on Defamation. This report proposed the adoption of the equivalent to ss $8(3)$ (a) and $8(3)$ (b) to remedy any confusion in the current law on the required level of truth to be proven. ${ }^{23}$ The Act includes specific guidelines as to pleading requirements for a defence of truth, and operates in conjunction with the common law rules to regulate the law of defamation. ${ }^{24}$

Section 8(3)(a) states that a defence of truth shall succeed if "the defendant proves that the imputations contained in the matter that is the subject of the proceedings were true, or not materially different from the truth." Television New Zealand Ltd $v$ Haines considered that this provision was a restatement of the common law position. ${ }^{25}$ Every detail of an alleged defamatory statement does not need to be proven true, as long as it is shown that the imputations are not materially different from the truth. ${ }^{26}$ A similar rule exists in England in s 5 of the Defamation Act 1952.

New Zealand courts maintain the original common law position that a defendant cannot allege a meaning that has not been pleaded by the plaintiff, then seek to justify that assigned meaning as true. ${ }^{27}$ Courts in England and Australia have both developed the common law so as to allow a lesser

21 Ibid.

22 Shah v Standard Bank, above n 15, at 263.

23 The McKay Report, above n 6, at 32.

24 Ibid, at 35; JF Burrows and Ursula Cheer Media Law in New Zealand (5th ed, Oxford University Press, Auckland, 2005) at 11

25 Television New Zealand Ltd v Haines, above n 5, at [55].

26 Ibid, at [49].

27 Ibid; Broadcasting Corporation of New Zealand v Crush [1988] 2 NZLR 234 (CA). 
meaning to be pleaded, believing it is possible that none of the plaintiff's alleged meanings will be what the defendant intended to convey. ${ }^{28}$ New Zealand law is in direct contrast to English law on this point. Although the natural construction of s 8(3)(a) appears to permit a defendant to prove alternative meanings, the New Zealand Court of Appeal ruled that a defendant is tied to the imputations pleaded by the plaintiff. ${ }^{29}$ The defendant can argue that the publication did not convey the alleged meanings at an earlier stage, thus meaning the plaintiff would fail in its claim. ${ }^{30}$ Haines held that s 8 was not intended to change this rule, and that a parallel inquiry into something the plaintiff was not complaining about was unhelpful. ${ }^{31}$

Section $8(3)$ (b) states that a defence of truth shall succeed "where the proceedings are based on all or any of the matter contained in a publication, the defendant proves that the publication taken as a whole was in substance true, or was in substance not materially different from the truth." Combined with s 8(2) allowing a defendant to prove the truth of any facts contained in the publication, this provision effectively overturns Templeton $v$ Jones ${ }^{32}$ and the "pick and choose" rule that applies in England. ${ }^{33}$ Section $8(3)$ (b) prevents a plaintiff from choosing to sue on some untrue aspect out of a substantially true publication, where the alleged statement does not materially injure the plaintiff's reputation in the context of the whole publication. If the sting of the whole publication is proven true in substance, and the words relied on by the plaintiff do not further damage the plaintiff's reputation, truth will succeed. ${ }^{34}$ Truth can be pleaded as a defence to the whole defamatory statement complained of, or as a defence to a severable part. ${ }^{35}$

Section 38 requires that "the defendant shall give particulars specifying (a) the statements that the defendant alleges are statements of fact; and (b) the facts and circumstances on which the

28 Polly Peck Holdings plc v Trelford [1986] QB 1000 (CA) at 1032; Woodger v Federal Capital Press of Australia Pty Ltd (1992) 106 FLR 183 (ACTSC); Mintoff v Associated Newspapers Group, The Times, 26 April 1989 (CA); S \& K Holdings Ltd v Throgmorton Publications Ltd [1972] 1 WLR 1036 (CA); Rath v Guardian News and Media Ltd [2008] EWHC 398 (QB); West Australian Newspapers Ltd v Elliott [2008] WASCA 172, 37 WAR 387.

29 Television New Zealand Ltd v Haines, above n 5, confirming Broadcasting Corporation of New Zealand v Crush, above n 27.

30 Broadcasting Corporation of New Zealand v Crush, above $\mathrm{n} 27$.

31 Television New Zealand Ltd v Haines, above n 5.

32 Templeton v Jones [1984] 1 NZLR 448 (CA).

33 Plato Films Ltd v Speidel [1961] AC 1090 (HL).

34 Burrows and Cheer, above n 24, at 146.

35 Laws of New Zealand, above n 8, at [86]. 
plaintiff relies in support of the allegation that those statements are true." A plea of truth without particulars can be struck out. ${ }^{36}$

\section{Evidence}

The defendant needs legally admissible and sufficient evidence to prove that the alleged imputations are true. Evidence is the method of proof of facts that are in issue, but can only be given in support of facts and evidence referred to in permitted particulars. ${ }^{37}$ Before making a plea, the defendant should ensure that there is reasonable evidence to support the plea on the balance of probability. ${ }^{38}$ Proving truth in defamation cases can sometimes compel media defendants to disclose their sources, which they are not necessarily required to do. ${ }^{39}$ Statements about indirect relationships or causes of events can be inherently difficult to prove by any method. The Evidence Act 2006 sets out the main requirements for evidence in New Zealand.

(a) Evidence Act 2006

Prior to this statute, evidence law had been largely judge-made, with some legislative amendments to meet specific concerns. ${ }^{40}$ The Evidence Act 2006 was introduced to make the law of evidence more certain, consistent and easy to access, and facilitate the admission of relevant and reliable evidence. ${ }^{41}$

Section 7 significantly provides for the admissibility of relevant evidence unless it is inadmissible under the Act or any other legislation. In accordance with the purpose of the Act, relevant evidence must have a tendency to prove a material proposition. ${ }^{42}$

Section 17 states that a hearsay statement is inadmissible except as provided for by statute. Section 18 further provides that a hearsay statement may be admissible if it is circumstantially reliable, and the maker of the statement is unavailable as a witness. Admissibility of hearsay evidence thus depends upon relevance and reliability. Under s 4, a hearsay statement is one offered in evidence to prove the truth of its contents. ${ }^{43}$ A statement offered for another purpose, such as to

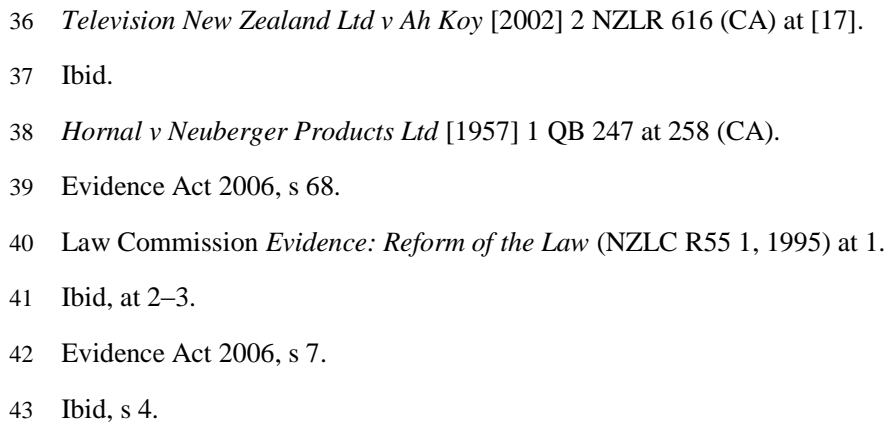


show that words were spoken, does not need to meet the s 18 admissibility test. ${ }^{44}$ Gatley explains that although hearsay evidence may be used to establish a primary fact, statements by an individual cannot themselves serve as primary facts to establish a defence of truth. ${ }^{45}$

Section 50 prevents reliance on judgments or findings of fact in civil proceedings as evidence of a fact that is in issue. The Law Commission believed this rule was necessary, given that parties in a civil proceeding can choose how to conduct their respective cases and which material to bring before the court. ${ }^{46}$ Even if the same issues are in dispute, proceedings can be substantially different. Exclusion of previous judgments was therefore considered the most suitable approach. ${ }^{47}$ Relevant findings and judgments which are not offered to prove a fact in issue may still be admissible under $\mathrm{s}$ 7.48

Considering the existing law on the pleading and evidential requirements for a defence of truth, this paper will now analyse the issues and ruling in Simunovich on the inadmissibility of third party particulars, assessing the integration of the relevant common law and statutory rules.

\section{APN NEW ZEALAND LTD V SIMUNOVICH FISHERIES LTD AND ORS}

\section{A Facts}

Simunovich Fisheries brought a defamation action against several defendants claiming extensive damages of almost $\$ 30$ million for allegations that they were guilty of corruption, and that the directors were corrupt and dishonest businessmen. ${ }^{49}$ The administration of the New Zealand fishing industry was a subject of public controversy. ${ }^{50}$ Each media defendant had published statements about Simunovich intentionally engaging in unlawful fishing practices, such as misrepresenting scampi catch quantities under the quota management system. Statements were also published on the relationship between the plaintiffs and the Ministry of Fisheries, alleging that Ministry officials had facilitated the unlawful practices of Simunovich. Several proceedings between 1993 and 2002 had previously dealt with the allocation of scampi fishing quotas. Judgments of the High Court and

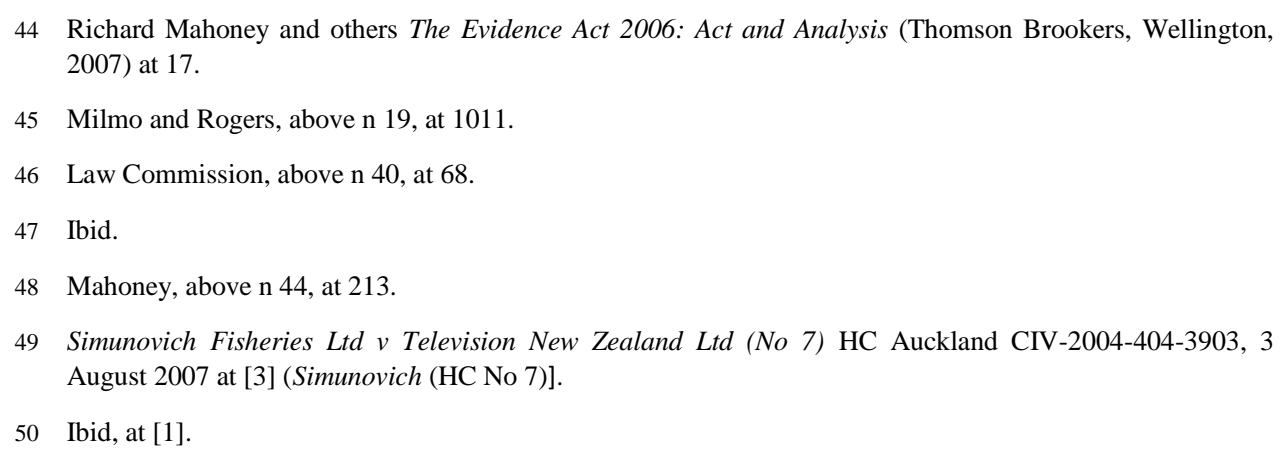


Court of Appeal had criticised the Ministry of Fisheries for its management of the fishery, with one holding that Simunovich had benefited from the Ministry's unlawful behaviour. ${ }^{51}$ In April 2002, Winston Peters delivered a speech in Parliament alleging corrupt practices involving the Simunovich fishery. ${ }^{52}$ These allegations led to the Solicitor-General commissioning a report on possible corruption in the Ministry. Television New Zealand (TVNZ) and the New Zealand Herald, operated by APN New Zealand (APN), both published media reports relating to Simunovich, and it is these publications that were subject to the defamation proceedings.

The parties reached a settlement of this defamation action in December 2009, but TVNZ has denied reports that the defendants paid in excess of $\$ 15$ million. ${ }^{53}$ Public apologies subsequently published retract any suggestion that Simunovich was involved in corrupt activities.

\section{B Issue}

Simunovich Fisheries claimed that each media publication was capable of carrying one or more of five defamatory meanings imputing corrupt and dishonest conduct. The plaintiffs argued both "tier one" and "tier two" meanings. These were that the plaintiffs were corrupt, or, alternatively, that there were serious grounds to believe they were corrupt. ${ }^{54}$ The defendants pleaded truth and honest opinion defences. The issue that was the subject of the appeal, which ultimately went to the Supreme Court, was the nature of particulars that a defendant could give. The critical disputed point was whether particulars for truth could extend to statements of others alleging that the plaintiffs are corrupt, or could reasonably be suspected of being corrupt. ${ }^{55}$

\section{Lower Courts}

The plaintiffs applied to strike out the third party particulars brought by the defendants for a truth defence against the "tier two" imputations. Several judgments on pre-trial applications were made in the High Court. In the seventh judgment, Allan $\mathrm{J}$ held that the repetition and conduct rules applied to third party statements as particulars, and that hearsay sources of evidence were inadmissible for the purpose of establishing facts for a truth defence. ${ }^{56}$ In considering s 38 of the

51 Official Assignee v Chief Executive of the Ministry of Fisheries [2002] 2 NZLR 722 (CA).

52 Simunovich Fisheries Ltd v Television New Zealand Ltd [2008] NZCA 350 at [3] [Simunovich (CA)].

53 Paul McBeth "TVNZ denies \$15 million pay-out to Simunovich, confirms settlement" (2010) Scoop <www.scoop.co.nz>.

54 Simunovich (CA), above n 52, at [16].

55 Simunovich (SC), above n 1, at [2].

56 Simunovich (HC No 7), above n 49, at [48]. 
Defamation Act, the Judge held that statements of others could constitute circumstances in support of a defence of truth, but were not primary facts. ${ }^{57}$

The Court of Appeal considered appeals arising from this High Court judgment. The judges discussed whether a third party statement was capable of establishing the truth of a defamatory imputation, and held that both the repetition and conduct rules would apply. ${ }^{58}$ Hearsay allegations were thus incapable of supporting a truth defence, and s 50 of the Evidence Act meant there was no exception for judicial decisions. The Court found that s 38 did not allow a defendant to rely upon assertions of others, even as circumstances. ${ }^{59}$ The third party particulars were all held to be inadmissible, but some could still be referred to as part of the context of the defence. The appeal was allowed in part, with amendments required to the truth defences as pleaded.

\section{Supreme Court}

The Supreme Court unanimously held that expressions of opinion by third parties may not be pleaded as particulars in a defence of truth to an allegation of reasonable grounds of suspicion. ${ }^{60}$ The repetition and conduct rules were applied, meaning the defendants could not rely on third party statements unless they could independently verify the truth of the underlying allegation. ${ }^{61}$ The Supreme Court upheld the Court of Appeal ruling that the required particulars are confined to "objectively provable primary facts". ${ }^{62}$ The Court found that a defendant must plead particulars of truth as a common law requirement, rather than under s 38 which relates to an honest opinion defence, despite its heading. ${ }^{63}$ The Court also held that $\mathrm{s} 8(3)$ (b) prevents a plaintiff pleading a "pick and choose" meaning, but a court must still find whether the allegation is part of a wider picture or is a severable sting. ${ }^{64}$

\section{IMPLICATIONS OF SIMUNOVICH ON THE DEFENCE OF TRUTH}

The Supreme Court ruling in Simunovich has made the establishment of a successful truth defence to a "tier two" imputation more difficult, as any third party statement relied upon cannot be pleaded unless it can be independently proven as true. After considering both the repetition and

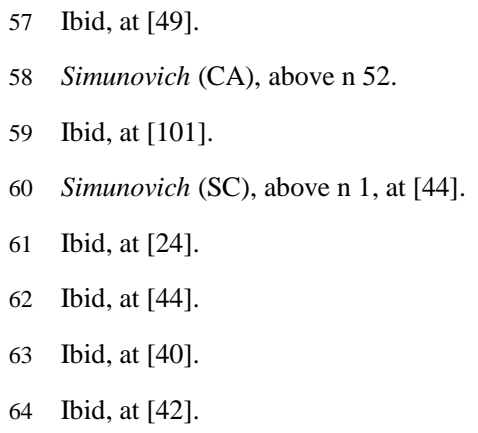


conduct rules and the Defamation Act 1992, the Court limited the available particulars and admissible evidence in support of a truth defence.

\section{A Establishing the Defence of Truth}

\section{Implications for pleadings}

(a) Development of pleadings in Simunovich

In the High Court, the defendants had pleaded a defence of truth under both s 8(3)(a) and s 8(3)(b) of the Defamation Act 1992. The Court held that Simunovich was entitled to a defined set of particulars. Allan J stated that the defendants should plead facts and circumstances separately, identifying which facts and circumstances supported the truth of each of the plaintiff's alleged imputations, and which supported the truth of the overall publication. The defendants argued that the repetition and conduct rules, as developed by English authorities, should not apply in New Zealand. However, Allan J held that there was nothing in the Defamation Act 1992 that suggested a different approach should be adopted. ${ }^{65}$

In the Court of Appeal, all three respondents made amended pleadings under s 8. TVNZ pleaded truth under s 8(3)(a) for the tier two meanings, and under s (8)(3)(b) in the alternative for all five alleged imputations of corruption. ${ }^{66}$ TVNZ attached several schedules to support its defence comprising lists of facts, including statements from others alleging Simunovich had acted unlawfully, but did not directly plead these as true facts. TVNZ also attempted to rely on these third party statements as circumstances in support of the s 8(3)(b) defence. APN pleaded truth under $s$ 8(3)(a) and did not invoke s 8(3)(b). ${ }^{67}$ APN also set out the separate facts and circumstances it relied on in support of the defence of truth, but like TVNZ, did not specifically plead the facts in the publication that it said were true. Barine, a competitor of Simunovich, pleaded facts in support of a s 8(3)(b) defence.

The particulars put forward by the defendants included statements from several reputable sources. Statements of judges and findings of fact in previous court judgments concerning corruption in fisheries were pleaded, giving rise to contentious arguments about the reliability of such a source in supporting a defence of truth. Allegations by a prominent politician claimed Simunovich had engaged in many unlawful practices on a large scale and over a long period of time. Extracts from a report commissioned by the Solicitor-General and affidavits from former Ministry employees were also adduced. ${ }^{68}$ The plaintiffs argued that the majority of each defendant's

65 Simunovich (HC No 7), above n 49, at [46].

66 Ibid, at [18].

67 Ibid, at [30].

68 Simunovich (SC), above n 1, at [6]. 
particulars were hearsay allegations and thus could not be admitted as evidence or facts and circumstances in support of a truth defence. However, the Court of Appeal held that the defendants needed to first identify the published facts that they claimed were true, then plead any supporting facts and circumstances that could show these facts were true. The pleadings of each defendant thus required revision to comply both with this formation and with the legal principles as discussed below.

(b) Form of particulars

Particulars in relation to the "tier one" meaning alleged by the plaintiffs were not at issue on appeal. The Court of Appeal in Simunovich had dismissed any idea that the method of proof of facts in issue should depend on the tier of meaning borne by the words. The Supreme Court held that the tier of meaning engaged was a "convenient general description" but should not dictate the permissible scope of particulars. ${ }^{69}$ A more serious allegation would require a greater degree of specificity, irrespective of the tier of meaning it alleged. However, it is arguable that if words can bear a "tier two" or "tier three" meaning, but are incapable of bearing a "tier one" meaning, a wider range of particulars should be allowable. Statements from a reliable third party source may be highly relevant to assist in proving that there were reasonable grounds to suspect misconduct, rather than proving the truth of actual misconduct. If misconduct is alleged in a judicial statement, for example, it is reasonable to allow a defendant to put this before the court in support of a truth defence for a "tier two" imputation. Such statements will not necessarily prove the truth of a "tier two" meaning on their own, but would give an argument more weight in comparison to their use against a "tier one" allegation.

TVNZ argued that as the plaintiff had not yet given particulars, material should not be struck out in this application. Regardless, the Supreme Court confirmed that the defendant's particulars must give "appropriate details of the facts and circumstances which are said to support the [truth] defence" to enable the plaintiff to prepare for trial. ${ }^{70}$ Particulars must state the facts or circumstances that can be supported by evidence which is both relevant and admissible for the purpose of proving truth. ${ }^{71}$ However, the defendant cannot plead particulars in a way that "transfer[s] the burden to the claimant of having to disprove them. ${ }^{\text {"72 }}$

(c) Repetition and conduct rules

Simunovich was significant as it considered a challenge to the relevance of the repetition and conduct rules for pleading a defence of truth of reasonable grounds for suspicion, since the adoption

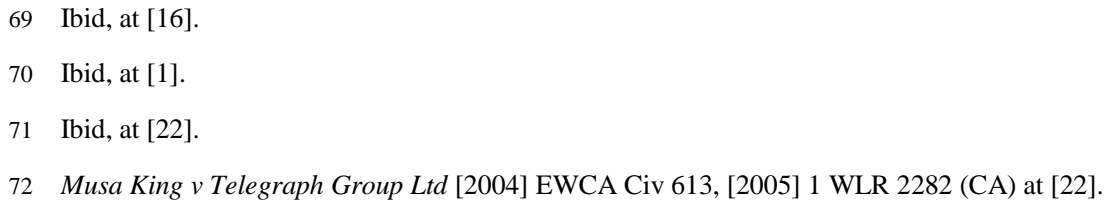


of the Defamation Act 1992, but confirmed the application of these rules. ${ }^{73}$ The Supreme Court concluded that the law of defamation in New Zealand should adopt the principles stated by Brooke LJ in Musa King regarding particulars pleaded in support of a defence of truth to an allegation of reasonable suspicion. ${ }^{74}$ Musa King stated that the repetition rule meant a defendant who republished a defamatory allegation could only succeed in a truth defence by proving that the underlying allegation was true, not just that the statement was made. ${ }^{75}$ For a "tier two" imputation, pleadings must include the primary facts that give rise to reasonable suspicion from objective evidence. Brooke LJ stated it is impermissible to plead third party statements as primary facts themselves, although such evidence could be used to establish a primary fact. The conduct rule was also held to apply, but in some cases Brooke LJ thought strong circumstantial evidence implicating the plaintiff could be enough to create reasonable grounds for suspicion.

The defendants in Simunovich could thus not rely on third party statements to prove the truth of their allegations, unless they could verify the facts underlying those statements. The defendants argued that these common law principles should not apply in New Zealand, as they are no longer the law in England. However, the Court found that as the primary English case relied on for this submission was concerned with partly privileged statements, this argument had no real standing. ${ }^{76}$ Qualified privilege is one exception to the repetition rule, but it still prevents the use of third party statements as particulars. Both the repetition and conduct rules remain part of English and New Zealand defamation law. The law in Australia is also similar to these principles regarding the inadmissibility of third party particulars in support of a defence of truth. ${ }^{77}$

The Supreme Court stated that the rationale for the repetition rule is that publishers have further disseminated the statement, especially in the case of media, so are as equally liable to ensure its truth as the original statement-maker. ${ }^{78}$ A person receiving the published third party statement may think as badly of the defamed plaintiff as if they had heard the statement from the third party themselves. ${ }^{79}$ The court held that the truth of the underlying facts must be proven, because the fact that another person asserted that Simunovich was a corrupt and dishonest company is insufficient to prove that there were reasonable grounds to suspect this. Mere rumour is not enough, as although

73 Simunovich (SC), above n 1, at [35].

74 Ibid.

75 Musa King, above n 72, at [22] per Brooke LJ.

76 Ibid, at [29]; Curistan v Times Newspapers Ltd [2008] EWCA Civ 432, [2009] 1 QB 231 (CA).

77 S, DJ v Channel Seven Adelaide Pty Ltd [2008] SASC 60.

78 Simunovich (SC), above n 1, at [24].

79 Simunovich (CA), above n 52, at [90]. 
this might suggest that an allegation is true, it would be unlikely to produce reasonable grounds for belief. ${ }^{80}$

The conduct rule states that because a defamatory imputation can allege improper conduct by the plaintiff, a defendant must demonstrate the relevant conduct of the plaintiff that establishes primary facts to support having reasonable grounds for suspicion. ${ }^{81}$ The sting in this case lies in the allegation that Simunovich took action, such as misreporting catch numbers, which establishes serious grounds to suspect corruption. The Supreme Court confirmed that a defence of truth based on reasonable suspicion should focus on "conduct of the plaintiff that gives rise to reasonable grounds of suspicion [when] objectively judged". ${ }^{82}$ This objective requirement removes the relevance of third party allegations that the plaintiff is guilty. The Supreme Court held that subjective opinions about truth would not necessarily prove the truth of a defamatory meaning, unless the underlying facts are independently verifiable. ${ }^{83}$

Even if these common law rules were held not to apply, it is likely that the hearsay rules in the Evidence Act 2006 would still limit the use of third party statements as evidence for the purpose of proving truth in New Zealand, although possibly not to the extent held in Simunovich. However, the Evidence Act provisions consider how particulars can be proven, not whether the particulars are legitimate. ${ }^{84}$ Without the common law rules, pleadings for a defence of truth to allegations of reasonable suspicion may have more scope to include reliable third party statements as facts. If the repetition rule was to no longer apply to tier two imputations, as was contended, many more defamatory allegations may come to be published in these terms. It would be undesirable to revoke the repetition and conduct rules, as both play a pivotal role in determining particulars for a defence of truth in defamation actions.

\section{(d) Defamation Act 1992}

Simunovich also considered further arguments regarding the application of the Defamation Act to pleadings for a defence of truth.

The plaintiffs argued that once a defendant pleaded a s 8(3)(a) defence, it could not then plead a s 8(3)(b) defence because the two were inherently contradictory claims. ${ }^{85}$ However, it was held in each Simunovich judgment that a defendant was entitled to rely on both subsections in pleading a

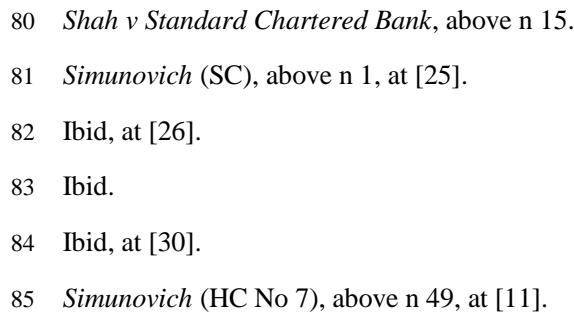


defence of truth. Under s 8(3)(a), a defendant can plead truth or substantial truth in answer to a plaintiff's pleaded imputation. Alternatively, they can also argue under s 8(3)(b) that the publication as a whole was true and that the specific imputation chosen by the plaintiff produced no further injury to the plaintiff's reputation. This is different from claiming that the publication as a whole did not have the imputation claimed by the plaintiff, as Simunovich had suggested in this case. A restriction such as that argued by the plaintiffs would be inconsistent with the purpose of the section to overcome unfairness for a defendant based on a plaintiff's selection of alleged imputations. ${ }^{86}$

The Supreme Court confirmed that under s 8(3)(a), a defendant may not set up an alternative lesser meaning and prove the truth of it, as was accepted in Broadcasting New Zealand $v$ Crush and Haines. ${ }^{87}$ Despite this being possible in England, New Zealand courts have followed the view that it should be the plaintiff's alleged meaning that must be justified as this avoids a case becoming unnecessarily complicated and time-consuming. In adopting the Musa King principles, the Supreme Court further held that a defendant cannot confine the basis for reasonable grounds of suspicion to facts of their own choosing. ${ }^{88}$

The Court of Appeal held that s 8(3)(b) overturned the "pick and choose" rule, and may be pleaded with or without s $8(3)(a) .{ }^{89}$ Simunovich is to some extent a "pick and choose" case, as the plaintiff pleads particular parts of each publication. The availability of s 8(3)(b) was confirmed on appeal, meaning the defendants could attempt to establish that their publications were substantially true, even if certain imputations that the plaintiff relied on were false. However, the Supreme Court noted that this point did not assist the defendants in arguing that their particulars were correct in these pre-trial applications so was irrelevant at this stage of the proceedings.

Another issue under the Defamation Act was whether the phrase "facts and circumstances" in $\mathrm{s}$ 38 allows a defendant to prove facts by proving that others alleged that the defamatory imputation was true. Allan $\mathbf{J}$ relied on this section to hold that the defendants could plead the assertions of others as circumstances, but not primary facts, in support of a truth defence. ${ }^{90}$ The Court of Appeal considered that s 38 contained the obligations for a defendant pleading truth, but that the repetition and conduct rules were significant in determining the scope of the required particulars to show facts and circumstances.

\footnotetext{
86 Defamation Bill 1988 (72-1) (explanatory note) at 8(3)(b).

87 Crush (CA), above n 27; Simunovich (SC), above n 1, at [31].

88 Ibid, at [22].

89 Simunovich (CA), above n 52, at [50]-[52].

90 Simunovich (HC No 7), above n 49, at [11].
} 
Conversely, the Supreme Court held that the scope of s 38 only applied to a "rolled-up" plea in support of honest opinion and truth combined, rather than truth alone. ${ }^{91}$ The heading of s 38 "misstates the purpose and the effect of the provision". ${ }^{92}$ However, even though the section does not apply to a defence of truth, particulars must still be provided for the defence of truth as a common law obligation. ${ }^{93}$ Where the plea is one of reasonable grounds of suspicion, the defendant must plead the primary facts that they claim are true and that give rise to those grounds. ${ }^{94}$ The common law requirement meant that the Supreme Court ruling on this matter did not have any practical significance for the pleadings of the defendants.

The Supreme Court held that third party assertions could still not be pleaded to establish a defence of truth, as they were prohibited by the repetition and conduct rules. Such statements may be able to be admitted as circumstantial evidence proving reasonable grounds to suspect under the Evidence Act as discussed below, but not as facts for the purpose of proving truth according to this judgment.

\section{B Implications for Evidence}

The evidence that the defendants in Simunovich could adduce was limited by the rulings on pleadings analysed above. The requirement for independent verification of third party statements meant that many of the defendants' particulars involving statements by others were likely to be inadmissible as pleadings. Because the defendants' particulars contravened both the repetition and conduct rules, the Courts considered whether the Evidence Act had altered the common law position.

\section{Evidence Act 2006}

The Supreme Court judgment clarifies that although relevant evidence is generally admissible under s 7(3) to prove the facts and circumstances relied on for a truth defence, including hearsay evidence, that does not mean that a hearsay statement can be a primary fact. Despite being prima facie inadmissible under s 17 , a third party statement may be admissible as circumstantial evidence under s 18 , if the statement establishes some conduct or circumstances that justify the truth of a primary fact. ${ }^{95}$ The repetition rule means that the secondary fact that a third party claimed that the primary fact was true cannot be a primary fact itself for the purpose of establishing a truth defence. However, the hearsay provisions under s17 and s18 mean that such third party statements may be

91 Simunovich (SC), above n 1, at [39].

92 Ibid.

93 Television New Zealand Ltd v Ah Koy, above n 36, at [17].

94 Crush and Hyams v Peterson [1991] 3 NZLR 648 (CA).

95 Musa King, above n 72, at [22] per Brooke LJ. 
able to be repeated as hearsay evidence to prove a primary fact in certain circumstances. These principles reconcile the application of common law rules and the requirements for hearsay evidence. The court held that repeating claims of others to support having reasonable grounds for suspicion is not sufficient to prove that reasonable grounds existed. However, this belief does not mean that third party statements should be inadmissible as a relevant supporting factor, whether or not they are able to prove the truth of the grounds by themselves. Statements that can objectively be relied upon may be a significant evidential source to support the existence of grounds for suspicion, and should thus not be excluded as evidence for this particular defence.

(a) Section 50

The Supreme Court held that findings of facts in other litigation could not be primary facts for evidential purposes in defamation law. Although their authorship lends them much reliability, the Court held that there is no exception for judicial decisions to be used to prove the existence of a primary fact. ${ }^{96}$ Section 50 reflects the rule expounded in the case that the defendants must be able to independently verify any third party statements they rely on, regardless of their dependability. The Court notes that the judicial statements relied upon by the defendants in this case do not suggest any corruption by the plaintiffs, despite criticising their actions, so would not support their defence of truth even if admissible. If the judicial evidence did contain significant allegations of corruption, the Court would still have been unlikely to admit it because of their view on the Evidence Act provision.

Simunovich held that reports of judicial proceedings can be referred to in court and may come under privilege, but cannot be relied on to prove the truth of a defamatory allegation. ${ }^{97}$ Conversely, this paper argues that objectively reliable third party statements should be admissible as evidence in support of a defence of truth to a tier two imputation. Judicial statements from previous litigation would certainly qualify as being objectively reliable and should thus be admissible for this specific defence, despite the general rule in s 50. The impact of the Simunovich decision on the inadmissibility of third party particulars in support of a defence of truth will now be assessed.

\section{$V$ SIGNIFICANCE OF THESE IMPLICATIONS}

\section{A Repercussions for Media Reporting}

\section{Establishing the defence of truth}

Simunovich will make it harder for defendants to establish the defence of truth, as available particulars and evidence are more limited. In some ways, this development is beneficial, as a plaintiff needs protection from potentially unreliable stories by defendants. Such defendants are

96 Simunovich (SC), above n 1, at [33].

97 Ibid. 
often large media companies that can make themselves loudly heard or persuade a plaintiff to settle out of court rather than succeed in their defamation claim. The prevalence of easily accessible digital publications in modern society further reflects the need to ensure there are sufficient safeguards against defamatory statements. However, the ruling in Simunovich takes this too far. Some advocates, unsurprisingly including a majority of the New Zealand media, argue that the requirements of defamation were already too much in favour of the plaintiff. ${ }^{98}$ A plaintiff does not have to prove that the statements made were false, that the defendant was at fault or that they suffered any loss. ${ }^{99}$ Truth is already a complex and difficult defence to successfully plead to the appropriate standard of proof with legally admissible evidence. ${ }^{100}$ The technical requirements of a truth plea may require a media defendant to disclose its sources which can undermine investigative journalism and lead to a chilling effect as discussed below. Publishers may believe information is true but be unable to legally verify it with absolute certainty. The media can either withhold the information and risk failing in their function of informing the public, or publish it and risk failing a defence of truth. ${ }^{101}$ The Courts should be reluctant to erect obstacles that prevent a defendant pleading all relevant material. Although truth is certainly a necessary defence for the protection of the plaintiff, the added high threshold of the Simunovich requirements is likely to have negative repercussions for media reporting.

\section{Inadmissible evidence}

Simunovich may also be questioned in regard to the ruling that statements from credible third parties, such as the judiciary, cannot be used to prove the truth of facts in issue. This view is developed from statutory and common law requirements such as s 50 of the Evidence Act 2006, but an exception to these rules for a defence of truth to a defamation claim may be needed. The purpose of evidence law is to help the fact-finder make factual determinations by ensuring there is access to all relevant and reliable evidence. ${ }^{102}$ It is difficult to reconcile s 18 , where hearsay evidence may be admissible in certain circumstances if it is "circumstantially reliable", and the rule in s 50. Requiring evidence to be independently verifiable is an unnecessary requirement where the evidence comes from highly objectively reliable sources, such as a judicial decision. Statements from these sources should be admissible in support of proving the truth of the existence of reasonable grounds for suspicion. If an allegation of misconduct is expressed in a judicial statement, this should be given

98 Ursula Cheer "Myths and Realities about the Chilling Effect: The New Zealand Media's Experience of Defamation Law" (2005) 13 TLJ 259.

99 Todd, above $\mathrm{n} 2$, at 835.

100 Geoffrey Palmer "The Law of Defamation in New Zealand - Its Recent Evolution and Problems" in Jeremy Finn and Stephen Todd (eds) Law, Liberty, Legislation: Essays in Honour of John Burrows QC (LexisNexis, Wellington, 2008) 337 at 340.

101 The McKay Report, above n 6, at 8 .

102 Law Commission, above n 40, at 2. 
some weight when considering whether grounds for suspicion of that misconduct exist. Repetition of these statements would probably not be enough for "tier one" allegations of guilt, as an allegation from even a highly reliable source does not mean that the misconduct actually occurred. However, such statements can contribute to having grounds to suspect the occurrence of misconduct, and should thus not be excluded as inadmissible evidence. The common law repetition rule prohibits repetition of another person's potentially defamatory allegation, but involves no consideration of the circumstances of the original statement. Juries in a defamation action are likely to be able to discern the difference between repeating an allegation from a passer-by and from an indisputably reputable source. A publisher should be able to at least partly rely on an allegation from an independently reliable source for a "tier two" imputation, as they are not saying that the allegation is true, but that it provides reasonable grounds for suspicion. ${ }^{103}$ Third party particulars may not be able to prove reasonable grounds to believe an allegation on their own, but, if reliable, would add persuasive evidential credibility to a certain interpretation of underlying facts.

The Simunovich interpretation of the law creates too high a threshold for admissible evidence. ${ }^{104}$ The Court of Appeal has endorsed the view that New Zealand has a relatively responsible print media compared to England. ${ }^{105}$ It is thus arguable that a lesser evidential standard than the United Kingdom is sufficient. Plaintiffs also face complex pleading and evidential requirements, yet the Simunovich ruling is a significant disadvantage for media defendants. Proving facts based on third party statements may now become a significant hurdle for defendants, if such statements cannot be independently proven to be true. There is sufficient justification to allow third party statements from an objectively reliable source to be admitted to support a defence of truth to a tier two allegation.

\section{Self-imposed media restrictions}

Because the truth defence is now harder to establish, media companies are likely to further limit themselves from publishing potentially defamatory stories as a result of Simunovich. Although this is valuable to some extent, the law without the added Simunovich restriction arguably achieved this outcome to a sufficient level. Cheer found that the operation of defamation law already produced some chilling effects on the media in 2005. ${ }^{106}$ This judgment may lead to an additional chilling effect, as media weigh up the likelihood of succeeding in a truth defence against the benefits of publishing a statement. Even if a successful defence is possible, the threat of a defamation action

103 Steven Price "Supreme Court to hear Defamation Case" (2008) Media Law Journal <www.medialawjournal.co.nz>.

104 Todd, above n 2, at 836.

105 Lange v Atkinson [2000] 3 NZLR 385 (CA) at 398.

106 Cheer, above n 98. 
may be enough to deter the media from publishing a statement. ${ }^{107}$ Stories that have a risk of defamation may be avoided even if believed to be true, affecting the reports that are published because of difficult evidential and pleading requirements. ${ }^{108}$ True statements may not be published, or may be subject to a media apology as in Simunovich, rather than a successful defence. ${ }^{109}$ Companies with low profit margins may especially have to restrict what they publish, if they do not have the option of settling a claim if a truth defence is not viable.

If a defence of truth fails, the court can find that higher damages are warranted if the injury to the plaintiff has worsened as a result. ${ }^{110}$ Because Simunovich has increased the difficulty of successfully establishing a truth defence, this risk may now be greater than some media can afford to take. However, as a defendant is exercising its legal right to plead a defence, this ground for increasing damages appears unfair. ${ }^{111}$ By having defamation claims brought against them, defendants can also receive added injury to their reputation as a result of negative publicity, yet there is no similar corresponding advantage given. Nevertheless, this inherent danger of pleading a truth defence will be further visible as a result of Simunovich.

These self-imposed media restrictions will occur even if publication is in the public interest. If stories with a high element of public interest are suppressed, this restriction has a detrimental effect on freedom of expression and can dampen public debate. ${ }^{112}$ It is beneficial for the public to gain knowledge of a reasonable belief of corruption in the fishing industry, if a reason for suspicion can be proven true by an objectively reliable source. Publication of true investigative journalism that fulfils the public interest should be encouraged by the judiciary, rather than made more difficult. ${ }^{113}$

\section{B Freedom of Expression versus Protection of Reputation}

Defamation is a restriction on the right of the media to freedom of expression, and the defence of truth somewhat limits that restraint by allowing true expression to be published. By making it more difficult to succeed with a truth defence, the implications of Simunovich mean that protection of an individual's reputation is given more weight than is appropriate when balanced against freedom of expression.

107 Eric Barendt Libel and the Media: The Chilling Effect (Oxford University Press, New York, 1997) at 190.

108 Todd, above n 2, at 835 .

109 Geoffrey Robertson and Andrew Nicol Media Law (Sweet \& Maxwell, London, 2007) at 145.

110 Hawkins v Ayers HC Auckland CP 1246/92, 6 March 1996 at 6; The McKay Report, above n 6, at 36.

111 Todd, above n 2, at 793.

112 Cheer, above n 98; Palmer, above n 100, at 337.

113 Milmo and Rogers, above n 19, at 309. 


\section{Bill Of Rights Act 1990}

The Bill of Rights Act expressly provides for the right of freedom of expression under s 14. ${ }^{114}$ Under s 5, this right is subject to such reasonable limits prescribed by law as can be demonstrably justified in a free and democratic society. The Defamation Act 1992 was enacted after the Bill of Rights Act, suggesting that the limits within it on freedom of expression were generally acceptable. It is arguable that Simunovich has unjustifiably restricted the media's freedom of expression in publishing a true defamatory statement, as allowed under the Defamation Act, by limiting the available evidence and particulars of the truth defence thus making it harder to successfully establish.

Freedom of expression reflects the basic principle that society should be entitled to a free flow of information and to participate in robust comment. ${ }^{115}$ This right is necessary for informed decision-making and effective democratic government. Nevertheless, protection of a person's reputation is also important in a civilised society. Individuals need protection against unwarranted criticism or false allegations being published about them. This right can undoubtedly constitute some limits on freedom of expression, but such limits must be reasonable and justified. ${ }^{116}$ Historically, it has been argued that considerations of a right to protection of reputation have outweighed the right to freedom of expression, contributing to a chilling effect on the media as discussed above. ${ }^{117}$

In Simunovich, protection of reputation is given more weight than freedom of expression, as it is made more difficult for a publisher to succeed with a defence to a defamation action. The Court of Appeal considered that if the repetition rule did not apply to tier two imputations, it would be easier to publish defamatory allegations by framing them in these terms, endangering reputations. ${ }^{118}$ This argument has some standing, but even if defamatory statements were published by alleging reasonable suspicion, the fact that an allegation was made by a third party would be unlikely to prove truth on its own. Evidence of conduct on which to base such suspicion would still be needed. A person's reputation would continue to be protected through a defamation action by other requirements needed for a successful defence. The defence of truth is essential in ensuring the media can defend its right to freedom of expression in publishing true statements. By not allowing reliable

114 For discussion on the application of the right to freedom of expression in defamation proceedings, see Rogers v Television New Zealand Ltd [2007] 1 NZLR 156 (CA) at [114]; Simunovich (CA), above n 52, at [89].

115 The McKay Report, above n 6, at 7.

116 Todd, above n 2, at 839 .

117 The McKay Report, above n 6, at 7.

118 Simunovich (CA), above n 52, at [89]-[92]. 
third party statements to support a defence of truth, Simunovich has tipped the balance too far in favour of protection of an individual's reputation.

\section{FURTHER POSSIBLE AMENDMENTS TO CURRENT LAW}

This paper has advocated that third party statements from an objectively reliable source should be admissible in support of a defence of truth to a tier two allegation, in contrast with the Simunovich decision. Other amendments to the defence of truth may also be possible.

\section{A Particulars}

Plaintiffs must give particulars for a defamation action, as well as defendants. The Faulks Committee in England rejected a proposal that the plaintiff should give particulars for a truth defence, believing it would confuse the rule that the burden of proof rests on the defendant. Particulars from the plaintiff can give a clear identification of the alleged imputations, helping both sides to prepare for trial. This rule is unlikely to be amended in New Zealand as it delimits the areas of dispute at an early stage. ${ }^{119}$

\section{Lesser meaning}

A defendant in England can plead that their published statement contained a lesser meaning than that alleged by the plaintiff, then prove the truth of that meaning. ${ }^{120}$ Crush held that this option is not available for pleadings in New Zealand, and defendants are confined to the imputations pleaded by the plaintiff. ${ }^{121}$ Simunovich confirmed this rule considering the words of s 8(3)(a). ${ }^{122}$ A possible amendment could allow defendants to plead a lesser meaning, producing a higher likelihood of success in establishing truth. This would mitigate some of the implications of Simunovich that have made the defence difficult for the media to establish, and would allow defendants to explain the meaning they intended to convey. Without the availability of this pleading, a plaintiff gains a distinct advantage. ${ }^{123}$ A defendant denying the plaintiff's alleged meaning is likely to have less credibility before a jury than a defendant that also puts forward an alternative meaning and proves its truth. The rejection of the lesser meaning plea may also affect the ability for a plaintiff to amend its claim to rely on lesser defamatory meanings at trial. ${ }^{124}$ However, this defence is procedurally undesirable as it would extend and complicate defamation proceedings. Because the plaintiff is

119 The McKay Report, above n 6, at 35.

120 Lucas-Box v News Group Newspapers Ltd [1986] 1 WLR 147 (CA).

121 Broadcasting Corporation of New Zealand v Crush, above n 27.

122 Simunovich (SC), above n 1, at [39].

123 Alan Ringwood "Defamation: The Court of Appeal's decision in TVNZ v Haines" (2005) Bell Gully <www.bellgully.com>.

124 Ibid. 
seeking a remedy, it is fair that they allege a conveyed defamatory meaning and seek to claim on that allegation. If a defendant could put forward an alternative meaning, this proposal may transfer the burden of proof to the plaintiff to disprove that meaning. This result would be contrary to the rule that the defendant must prove the truth of its statements, rather than the plaintiff to prove falsity. ${ }^{125}$

\section{B Qualified Privilege Extension}

A defendant also has other defences besides truth that it may establish against a defamation claim, such as honest opinion and privilege. However, New Zealand does not have the Reynolds defence of qualified privilege that exists in England. ${ }^{126}$

The Court of Appeal in Lange $v$ Atkinson developed a defence of qualified privilege available to those elected or seeking election to Parliament. ${ }^{127}$ The Supreme Court has not yet considered whether a qualified privilege defence founded on responsible journalism should apply in this country. ${ }^{128}$ The Committee on Defamation proposed a wider qualified privilege defence for New Zealand, available where the publication was in the public interest and where the publisher has acted with reasonable care and given the defamed person a chance to publish a reply explaining the alleged statement. ${ }^{129}$ The Committee thought this defence would mitigate the chilling effect on the media produced by the defamation law. Lange held that the media industry in New Zealand was largely more responsible than their English counterparts, and such a defence was unnecessary. ${ }^{130}$ It is arguable that since the Lange judgment, the New Zealand media has become increasingly global with more outlets being able to publish widespread stories. If a criterion of responsible journalism became part of a wider qualified privilege defence, publishers could show that although they may have relied on third party statements, they ensured that these sources were reliable and acted with reasonable care in reporting that there were only grounds for suspicion as a result, rather than actual guilt.

Simunovich stated that allowing a general qualified privilege defence in New Zealand would not necessarily affect the pleading and evidential requirements of the defence of truth. ${ }^{131}$ Because the current defence of qualified privilege in New Zealand is so narrowly cast, it is arguable that the

\footnotetext{
125 Defamation Act 1992, s 8.

126 Reynolds $v$ Times Newspapers [2001] 2 AC 127 (HL).

127 Lange v Atkinson [1998] 3 NZLR 424 (CA) at 467-468.

128 Simunovich (SC), above n 1, at [31].

129 The McKay Report, above n 6, at 9-10.

130 Palmer, above n 100, at 345.

131 Simunovich (SC), above n 1, at [31].
} 
defence of truth should be made more accessible as an alternative option. An expansion to the defence could allow certain statements from reliable sources to be admissible. This option would be less contentious than implementing a responsible journalism defence, yet would be fairer to defendants and more in line with similar jurisdictions. If the courts are not prepared to follow England and Canada in developing a Reynolds-based qualified privilege defence, allowing third party statements as particulars would increase the likelihood of a media defendant being able to successfully establish a truth defence, at least to a tier two imputation.

\section{CONCLUSION}

Simunovich was a significant judgment on the establishment of a successful defence of truth in New Zealand. The case clarified the form of pleadings and evidence necessary to prove the truth of an alleged defamatory meaning, confirming the application of the repetition and conduct rules. Simunovich created a distinct disadvantage for media defendants by limiting the availability of third party statements as particulars and evidence for the purpose of proving the truth, unless the underlying facts of such a statement can be independently proven to be true. This paper has shown that making such statements inadmissible in support of a defence to a "tier two" imputation, even if they come from objectively reliable sources, is an undesirable development of New Zealand law. Courts should be reluctant to erect obstacles that may prevent a defendant from submitting relevant and reliable evidence. The increased prevalence of widespread digital publications in modern society reflects a need to ensure there are sufficient safeguards against defamatory statements. However, the existence of defamation law itself gives wide-ranging protection against injury to a person's reputation. The defence of truth is necessary to protect the right of the media to freedom of expression, and should not be unjustifiably restricted by technical pleading and evidential requirements.

This essay recommends that the Simunovich rule on third party statements be amended to allow such particulars to be admitted in support of a defence of truth to an alleged defamatory meaning of reasonable grounds of suspicion, where the statements come from an objectively reliable source such as the judiciary. Such statements may not be admissible to prove a "tier one" meaning of actual misconduct, as merely repeating an allegation does not prove its underlying truth. However, reliable statements by a third party can be highly relevant in proving the existence of reasonable grounds to suspect misconduct. A specific provision should be inserted into the Defamation Act to allow for this exception. Third party particulars will not necessarily prove the truth of allegations of suspicion by themselves, but should be able to be considered by the court alongside other relevant and reliable evidence. This principle would reduce the possibility of the media self-imposing further restrictions on publication of potentially defamatory statements, especially where publication may be in the public interest. A plaintiff's reputation would still receive continued protection from the remaining requirements of the defence of truth, especially given that this proposal applies only to tier two imputations. Although difficulties may arise in determining what constitutes an objectively reliable 
source, the relaxation of this rule would remove the high burden placed on defendants in proving the defence of truth, in contrast to the advantages held by plaintiffs in a defamation action. 
(2011) 42 VUWLR 